\title{
Longitudinal patterns of fish assemblages in mountain streams from tropical forest biome
}

\author{
João Fernando Marques da Silva ${ }^{1,3}$, Cibele Bender Raio ${ }^{2}$, \\ Débora Fernandes Silva Bernardino ${ }^{I} \&$ Sirlei Terezinha Bennemann ${ }^{1}$ \\ ${ }^{1}$ Laboratório de Ecologia Trófica, Departamento de Biologia Animal e Vegetal, \\ Centro de Ciências Biológicas, Universidade Estadual de Londrina - UEL, \\ Rod. Celso Garcia Cid, Pr 445 Km 380, CEP 86051-980, Londrina, PR, Brasil. http://www.uel.br/ \\ ${ }^{2}$ Laboratório de Biologia e Genética de Peixes, Departamento de Morfologia, \\ Instituto de Biociências, Universidade Estadual Paulista Júlio de Mesquita Filho - UNESP, \\ Distrito de Rubião Junior, s/n, CEP 18618-970, Botucatu, SP, Brasil. http://www.ibb.unesp.br/ \\ ${ }^{3}$ Corresponding author: João Fernando Marques da Silva, e-mail: jfm.bio@gmail.com
}

SILVA, J.F.M., RAIO, C.B., BERNARDINO, D.F.S. \& BENNEMANN, S.T. Longitudinal patterns of fish assemblages in mountain streams from tropical forest biome. Biota Neotrop. 13(3): http://www.biotaneotropica. org.br/v13n3/en/abstract?article+bn01213032013

\begin{abstract}
The aim of this study was to verify structure patterns in fish assemblages in mountain streams of the Rio Tibagi basin through the characterization of spatial and temporal variations in the composition of fish species. Samples were collected in three segments of the Varanal, João Pinheiro and Rio Preto streams. We collected 1154 specimens belonging to 21 species. The most abundant orders were Characiformes $(59.01 \pm 2.84 \%)$ and Siluriformes $(39.34 \pm 2.82 \%)$. Phalloceros harpagos was the most abundant species with 433 individuals, followed by Trichomycterus aff. davisi, with 292 individuals. No temporal variations (between seasons) were detected, but the cluster analysis suggests a separation of species composition between the segments closer to the headwaters and those more distant. The first two axes of the Canonical Correspondence Analysis (CCA) explained 80.09\% of the variation in species abundance, and the variables that structured the fish assemblages in those streams were the stream width, depth, water speed, flow rate, conductivity and $\mathrm{pH}$.
\end{abstract}

Keywords: ichthyofauna, freshwater fishes, neotropical fishes, low order streams, Tibagi river basin.

SILVA, J.F.M., RAIO, C.B., BERNARDINO, D.F.S. \& BENNEMANN, S.T. Padrões longitudinais das assembleias de peixes em riachos de montanha pertencentes ao bioma de floresta tropical. Biota Neotrop. 13(3): http://www.biotaneotropica.org.br/v13n3/pt/abstract?article+bn01213032013

Resumo: O objetivo deste trabalho foi verificar padrões na estrutura de assembleias de peixes nos riachos de montanha da bacia do rio Tibagi através da caracterização de variações espaciais e temporais na composição de espécies de peixes. Foram realizadas coletas em três trechos dos riachos Varanal, João Pinheiro e Rio Preto. No total foram coletadas 21 espécies, em um total de 1154 indivíduos. As ordens mais abundantes foram Characiformes $(59,01 \pm 2,84 \%)$ e Siluriformes $(39,34 \pm 2,82 \%)$. Phalloceros harpagos foi a espécie mais abundante, com 433 indivíduos, seguida por Trichomycterus aff.davisi com 292 indivíduos. Não foi verificada variação temporal (entre estações), mas a análise de agrupamento sugere uma separação na composição de espécies entre os trechos mais próximos das nascentes dos trechos mais afastados. Os dois primeiros eixos da Análise de Correspondência Canônica (CCA) explicaram 80,09\% da variação na distribuição em abundância das espécies de peixes, sendo que as variáveis que estruturam a assembleia de peixes nos riachos estudados foram a largura, a profundidade, a velocidade da água, a vazão, a condutividade e o $\mathrm{pH}$ dos riachos.

Palavras-chave: ictiofauna, peixes de água doce, peixes neotropicais, riachos de baixa ordem, bacia do rio Tibagi. 


\section{Introduction}

The highest richness of fish on the planet is found in tropical waters (Lowe-McConnel 1999) and, in South America, the Amazônica and Paraná watersheds have most of the species (Santos \& Ferreira 1999). Langeani et al. (2007), in a review of the Upper Paraná watershed ichthyofauna, found that $65 \%$ of the fish species present in this watershed are of small size, with the majority occurring in streams and headwaters regions, environments that have the highest number of novelties in new species and generates relevant information about the ichthyofauna.

The Tibagi river basin, included in the Upper Paraná watershed, is located in the Atlantic Rain Forest, one of the most important and threatened biomes of the world (Brasil 2002). Aquatic ecosystems belonging to this biome are subject to constant anthropogenic threats, and the main causes of loss of diversity are the disturbance of riparian vegetation, introduction of invasive species and the physical changes of the system (Barrella et al. 2000).

The Tibagi river presents high importance to the Paraná State in both economic and social aspects (Medri et al. 2002), and it has been intensively studied during the last decades (e.g., Bennemann et al. 1995, Shibatta et al. 2002, 2007). The lower order channel segments of the Tibagi basin have a high richness of small size fish species, but also show a wide richness variation among different tributaries (Shibatta \& Cheida 2003).

Abilhoa et al. (2011) analyzing ecological patterns and conservation of the Atlantic Rain Forest streams pointed that it's highly important to divide areas into units with similar fish assemblages, natural communities and ecosystem dynamic. Thus, this study aimed to verify whether the mountain streams of the Tibagi river basin present spatial and temporal patterns in their structure and composition of the fish assemblage. For this, the fish fauna of three mountain streams of the Tibagi river basin were analyzed regarding their richness, spatial and temporal variation in fish species composition and possible relationships between the sampled species and environmental variables in each sampled segment. In this way, we hope to contribute to the knowledge about the ecology of mountain stream fishes of the Atlantic Rain Forest.

\section{Material and Methods}

\section{Study area}

Samples were taken in the headwater, middle portion and mouth segments of the Varanal, João Pinheiro and in the upper portion of the Rio Preto streams (Figures 1 and 2). The order of each sampled segment was defined with aid of cartographic letters with scale 1:250,000 (Strahler 1957). The Varanal stream is a tributary of the Tibagi River located in a Private Reserve of Natural Heritage and was defined as a referential mountain stream for comparison with other streams of the Tibagi river basin due to its high biotic integrity (Azevedo et al. 2008, Shibatta et al. 2008, Bennemann et al. 2008). The first sampled segment of the Varanal (V-1) is of first order and has narrow and shallow bed with clayey soil and puddles with deposition of litter. The second sampled segment (V-2) is of second order and presents fast water flow in the rapids and slow flow in pools, the substrate is composed of sand and pebbles of different sizes. The last sampled segment of the Varanal (V-3) is also of second order, but has a strong influence of the Tibagi River. It is a well seated segment with bounds on the banks formed by clay and rocks. The substrate is mostly clay with little sand and some rocks, forming areas of rapids.

The João Pinheiro stream is a sub tributary of the Tibagi River and it is located in the Fazenda Monte Alegre Ecological Park. The first sampled segment of this stream (JP-1) is of first order and it is located close to a commercial plantation of Araucaria. The substrate is composed by sand and pebbles and it is common the presence of small waterfalls. The second sampled segment (JP-2) is of second order and despite being located in an Ecological Park, presents evidence

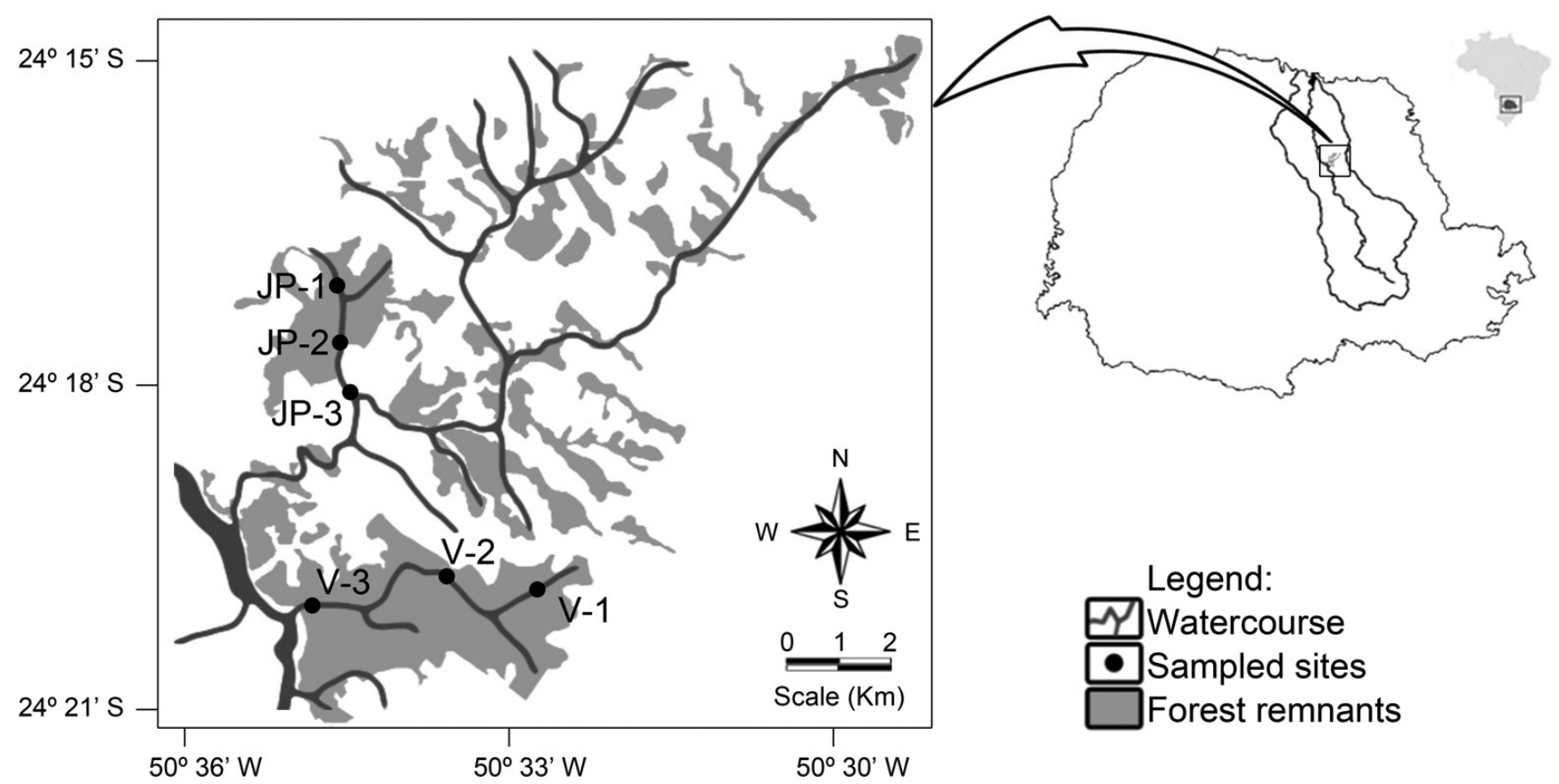

Figure 1. Sampled segments in the Varanal (V) and João Pinheiro streams (JP), conservation status of forest remnants of Atlantic Rain Forest biome and the location of Tibagi river basin in the Paraná State, Brazil. Modified from: Fundação SOS Mata Atlântica \& Instituto Nacional de Pesquisas Espaciais (Fundação... 2011) and Instituto de Terras, Cartografia e Geociências (Instituto... 2011). 


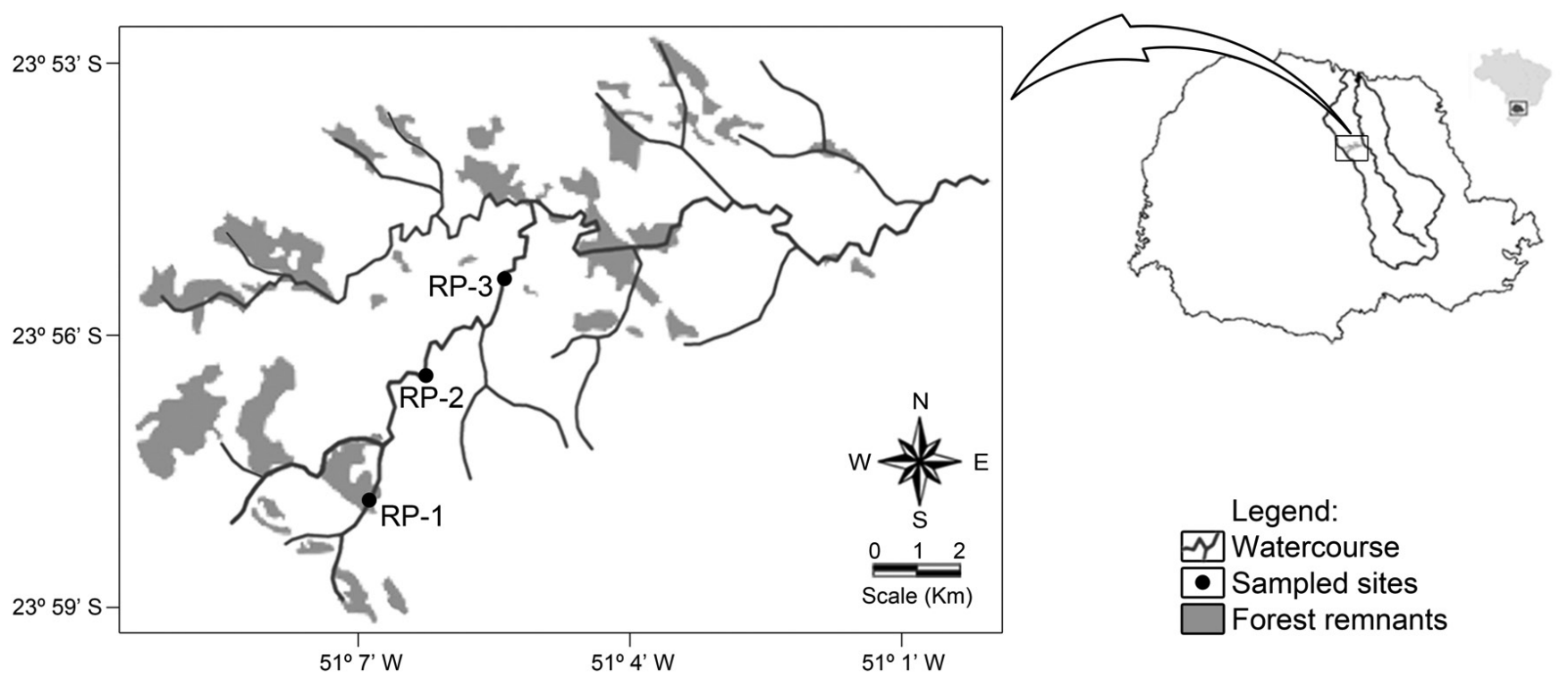

Figure 2. Sampled segments in the Rio Preto stream (RP), conservation status of forest remnants of Atlantic Rain Forest biome and the location of Tibagi river basin in the Paraná State, Brazil. Modified from: Fundação SOS Mata Atlântica \& Instituto Nacional de Pesquisas Espaciais (Fundação... 2011) and Instituto de Terras, Cartografia e Geociências (Instituto... 2011).

of anthropogenic land use. It is located downstream of an artificial lake built in the 1960s for sport fishing. The bottom has large deposits of sand and there are some flooded areas with submerged marginal vegetation. The last sampled segment (JP-3) is of second order with obvious alterations. The riparian vegetation suffered evident deforestation and a large flooded area is formed at the point where the João Pinheiro stream flows into the Harmony River. The bottom is muddy with stretches of exposed soil on the banks.

The Rio Preto stream is a sub tributary of the Tibagi River and its origin is located in the municipality of Mauá da Serra - PR at an altitude of 1100 meters and flows into the Apucarana river at 650 meters of altitude as a fourth order river. However, only the upper portion of the Rio Preto stream, which has characteristics of mountain stream, was sampled in this study (Figure 2). The first sampled segment (RP-1) is of second order and is located in a forest remnant. It presents diverse and stable habitats with bottom formed by pebbles and gravel. The second segment (RP-2) is of third order and the substrate has been totally modified. In the past pebbles from the bottom were removed to be used as masonry material. Currently the bottom is covered with mud deposits, it presents few areas with rapids, the riparian vegetation suffered deforestation, and the margins present stretches of exposed soil and unstable banks. The last segment (RP-3) is also of third order and it is embedded in a matrix of eucalyptus. It presents fast flow habitats and backwaters with diverse structure, the bottom is composed by sand and pebbles. It is worth to note that part of this stretch was channeled due to a rural country road.

\section{Sampling}

Four samples were taken in each segment, one in each annual season (autumn, winter, spring and summer). In the Varanal the samples were taken on February, April, July and November of 2005, in the João Pinheiro on July and November of 2008 and February and May of 2009, and in the Rio Preto on July and October of 2010 and February and May of 2011. The sampling on the three streams followed the methodology described by Bennemann \& Galves (2008). Each segment had $75 \mathrm{~m}$ of their length blocked with gill nets $(2 \mathrm{~mm}$ mesh) in order to prevent escape of organisms. All samples were made during daytime for an hour and several methods were applied in order to better sample the community in the streams. On banks and litter areas fish were collected with sieves ( $2 \mathrm{~mm}$ mesh) and on corridor areas of the streams the fish were captured by trawl (2 $\mathrm{mm}$ mesh). In pools and when the water level was higher were used gill nets of mesh sizes 2.4 and $4.0 \mathrm{~cm}$ between opposing knots.

In the field the fishes were anesthetized with Benzocaine ( 0.1 g. $\left.\mathrm{L}^{-1}\right)$ and fixed in $10 \%$ formalin. After five days the organisms were washed in current water and stored in $70 \%$ ethanol for later sorting and identification. The identifications were made with the aid of scientific literature (Shibatta et al. 2002, 2008), besides comparisons with testimony specimens at the Museum of Zoology of the State University of Londrina (MZUEL), where the sampled specimens were also deposited as testimony.

Each segment was located geographically through GPS and the following environmental factors were recorded during each sample: $\mathrm{pH}$, dissolved oxygen $\left(\mathrm{mg} . \mathrm{L}^{-1}\right)$, electrical conductivity $\left(\mu \mathrm{S} . \mathrm{cm}^{-1}\right)$ and water temperature $\left({ }^{\circ} \mathrm{C}\right)$, using a multifunction probe YSI model 85. The width and depth $(\mathrm{m})$ of each segment were obtained from the mean of 10 measurements along the $75 \mathrm{~m}$ using a measuring tape and a scaled rod. The water speed $\left(\mathrm{m} . \mathrm{s}^{-1}\right)$ was determined from the mean time a float device toke to travel a distance of five meters in 10 repetitions. The values of width, depth and speed were used to calculate the flow rate $\left(\mathrm{m}^{3} \cdot \mathrm{s}^{-1}\right)$ of each segment.

\section{Data analysis}

The abundance of fish species was square-root transformed to reduce the effect of the most representative species and environmental data were normalized by the mean of the analyzed variable (subtracting the mean and dividing by the standard deviation, for each variable). To test the null hypothesis that there was no difference in community composition between segments (spatial differences) and between seasons (temporal difference) for each stream, a similarity matrix was calculated using the Bray-Curtis measure of similarity followed by an analysis of similarity (ANOSIM) with 1000 permutations to examine statistical significance between samples (Clarke 1993). 
Nonmetric multidimensional scaling (NMDS) with 1000 restarts was used to ordinate the similarity data. The result of MDS ordination is a map where the position of each sample is determined by its distance from all the other samples in the analysis, and the 'stress' of the plot is a measure of how good the estimate was. Stress under 0.1 corresponds to an ideal ordination, between 0.1 and 0.2 indicates a useful two-dimensional picture and greater than 0.2 indicates that the plot is close to random. The patterns of distribution of the fish community between the streams were tested with a clustering analysis (group-average linking) and the resultant dendrogram was tested for group differences, using a similarity profile test (SIMPROF) with 1000 simulations. The similarity percentage contribution (SIMPER) of each species to the significant clusters was assessed to objectively classify species combinations and stream segments (Clarke 1993).

The environmental data were summarized using a principal components analysis (PCA). A Canonical Correspondence Analysis (CCA, Ter Braak 1986) was performed to verify the distribution patterns of the fish species along the environmental gradient. The abundance of the species which better contributed to the differentiation of the groups formed by the cluster analysis, according to the SIMPER test, was used as a dependent variable. The influence of each environmental variable was verified by the function "envfit" which uses the $\mathrm{r}^{2}$ value and several randomizations (1000 permutations) to define the significance of these variables. After obtaining the CCA model, the "anova" function was used to test whether the CCA obtained was significant. The CCA was performed on the R platform - R Development Core Team (Development... 2012), package 'vegan' (Oksanen 2011). The other analyses were performed in the statistical software PRIMER (Clarke \& Gorley 2006) with significance level of 0.05 .

\section{Results}

The mean values of the physical and chemical attributes for each sampling segment from the three streams are presented in Table 1. The principal component analysis produced a matrix of physical and chemical variables and two axes were retained for interpretation (cumulative explained variance $=61.0 \%$; Figure 3 ). The first axis (eigenvalue: 3.63; variation explained: $40.30 \%$ ) was the most important. The environmental variables that were positively correlated with the axis 1 were width, depth, water speed and flow rate (eigenvectors: $0.482,0.473,0.432,0.518$, respectively), variables related to the size of the streams, separating the segments according to their fluvial hierarchy.

A total of 1,154 individuals were collected corresponding to four orders, 10 families, 17 genera and 21 species (Table 2).
Among the specimens collected, $59.01 \pm 2.84 \%$ belong to the order Characiformes, $39.34 \pm 2.82 \%$ to the order Siluriformes, and $1.65 \pm 0.73 \%$ to the orders Gymnotiformes and Perciformes. The most abundant species was Phalloceros harpagos (37.52 $\pm 2.79 \%)$, followed by Trichomycterus aff. davisi $(25.30 \pm 2.51 \%)$, Astyanax aff. paranae $(10.75 \pm 1.79 \%)$, Corydoras ehrhardti $(9.71 \pm 1.71 \%)$ and Piabina argentea $(7.63 \pm 1.53 \%)$. The Varanal showed the highest species richness (13 species) followed by the João Pinheiro (12 species), while the Rio Preto had the lowest richness (9 species).

No significant difference of temporal composition among the fish community was found for each stream (ANOSIM; Varanal: $r=-0.114, p=0.873$; João Pinheiro: $r=-0.269, p=0.967$; Rio Preto: $r=-0.259, p=0.982$ ), however the analysis of similarity showed that the community composition differed mostly among the different segments (ANOSIM; Varanal: $r=0.287, p=0.007$; João Pinheiro: $r=0.961, p=0.001$; Rio Preto: $r=0.604, p=0.001)$. Indeed, both the dendrogram from the cluster analysis with the SIMPROF test and the nonmetric multidimensional scaling revealed a high degree of spatial structure in the fish community (Figure 4). The winter sample for segment V-1 was removed from the cluster and NMDS analyses because no fish were collected in this sample.

The first cluster (group A) was composed of the mouth segments of the Varanal and Rio Preto. The SIMPER evidenced that this group is defined by the species Hypostomus ancistroides and Astyanax aff. paranae, accounting for $39.67 \%$ and $28.96 \%$ of the internal group similarity, respectively. The next cluster (group B) was composed of the headwaters and middle segments of the three sampled streams and Trichomycterus aff. davisi and Phalloceros harpagos contributed with $72.69 \%$ and $23.02 \%$ of the similarity of this cluster. The last cluster (group c) encompassed only the mouth segment of the João Pinheiro and Corydoras ehrhardti and Geophagus brasiliensis accounted for $54.24 \%$ and $21.87 \%$ of this cluster internal similarity.

The canonical correspondence analysis (CCA) was significant $(p=0.015)$ and explained $80.09 \%$ of the variation in the distribution of the fish species abundance $(50.39 \%$ in the first axis and $29.70 \%$ in the second). The significant environmental variables in the distribution of the ichthyofauna were the stream width, depth, water speed, flow rate, conductivity and $\mathrm{pH}$ (Table 3 ). According to the first axis, the species $T$. aff. davisi, $P$. harpagos, $A$. aff. paranae and $H$. ancistroides were present mainly in wider segments, with higher flow rate and $\mathrm{pH}$, unlike G. brasiliensis and C. ehrhardti that were related to narrower portions with higher conductivity. The second axis of the CCA still separated $T$. aff. davisi from the other species, which was related to narrower and shallower segments, with lower conductivity values (Figure 5).

Table 1. Mean values of the physical and chemical water parameters sampled in Varanal, João Pinheiro and Rio Preto streams.

\begin{tabular}{|c|c|c|c|c|c|c|c|c|c|}
\hline & \multicolumn{3}{|c|}{ Varanal } & \multicolumn{3}{|c|}{ João Pinheiro } & \multicolumn{3}{|c|}{ Rio Preto } \\
\hline & $\mathrm{V}-1$ & $\mathrm{~V}-2$ & $\mathrm{~V}-3$ & JP-1 & JP-2 & JP-3 & RP-1 & RP-2 & RP-3 \\
\hline Altitude (m) & 840 & 707 & 637 & 812 & 741 & 711 & 906 & 858 & 821 \\
\hline Width (m) & 0.90 & 3.64 & 3.34 & 0.79 & 1.92 & 1.46 & 2.64 & 10.46 & 10.28 \\
\hline Depth (m) & 0.16 & 0.28 & 0.46 & 0.07 & 0.16 & 0.33 & 0.26 & 0.75 & 0.47 \\
\hline Water speed $\left(\mathrm{m} \cdot \mathrm{s}^{-1}\right)$ & 0.21 & 0.25 & 0.37 & 0.14 & 0.23 & 0.27 & 0.38 & 0.30 & 0.64 \\
\hline Flow rate $\left(\mathrm{m}^{3} \cdot \mathrm{s}^{-1}\right)$ & 0.03 & 0.27 & 0.58 & 0.01 & 0.11 & 0.15 & 0.26 & 2.34 & 3.08 \\
\hline $\mathrm{pH}$ & 8.13 & 8.11 & 8.24 & 6.71 & 6.76 & 6.36 & 8.34 & 7.99 & 8.14 \\
\hline Dissolved oxygen (mg.L $\mathrm{L}^{-1}$ ) & 7.45 & 8.05 & 7.90 & 9.83 & 9.47 & 9.50 & 8.65 & 8.98 & 9.22 \\
\hline Conductivity $\left(\mu \mathrm{S} . \mathrm{cm}^{-1}\right)$ & 16.76 & 21.03 & 20.98 & 29.71 & 46.43 & 45.80 & 25.45 & 36.43 & 40.23 \\
\hline Temperature $\left({ }^{\circ} \mathrm{C}\right)$ & 17.58 & 14.65 & 15.28 & 16.93 & 16.87 & 18.70 & 16.83 & 17.45 & 18.05 \\
\hline Fluvial hierarchy & 1 & 2 & 2 & 1 & 2 & 2 & 2 & 3 & 3 \\
\hline
\end{tabular}




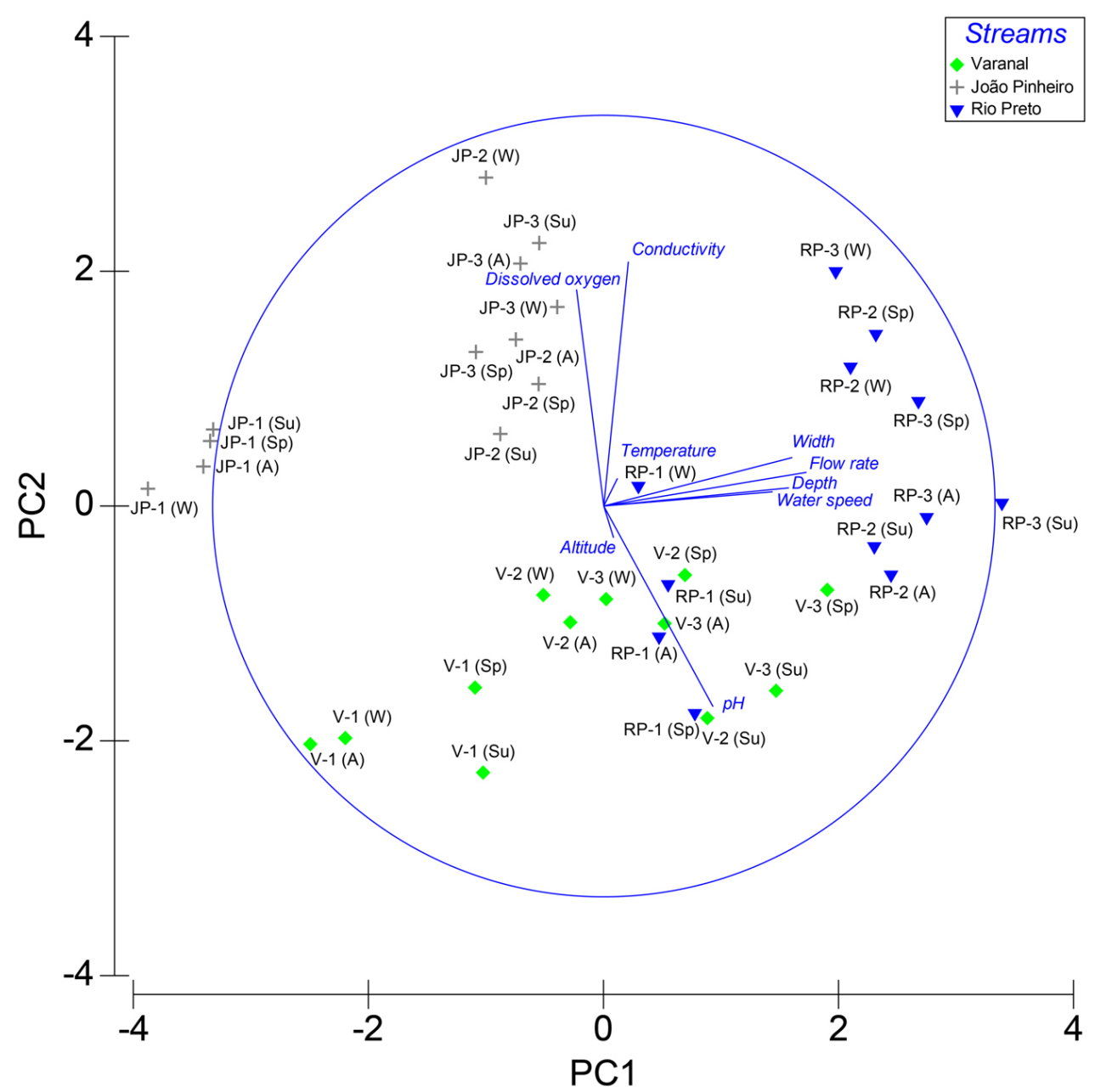

Figure 3. Principal component analysis $(\mathrm{PCA}$; $\mathrm{PC} 1 \times \mathrm{PC} 2)$ of physical and chemical variables sampled in the Varanal, João Pinheiro and Rio Preto streams (Su: summer; A: autumn; W: winter; Sp: spring).

\section{Discussion}

From the collected fish species, $98.35 \pm 0.73 \%$ belonged to the orders Characiformes and Siluriformes, reflecting the expected pattern for Neotropical streams (e.g., Castro 1999, Casatti et al. 2001, Shibatta \& Cheida 2003, Shibatta et al. 2007, Couto \& Aquino 2011). The most abundant species was Phalloceros harpagos, which was mainly collected in the middle segment of the João Pinheiro stream and in the headwater and middle segments of the Rio Preto (JP-2, RP-1 and RP-2). According to Casatti et al. (2001), this species is related to lentic microhabitats. The middle segment of the João Pinheiro (JP-2) has flooded areas with submerged marginal vegetation, which may provide microhabitats for the establishment of the species. The middle segment of the Rio Preto (RP-2), which presents disturbed substrate, had the highest abundance of $P$. harpagos, demonstrating the opportunistic characteristic of this species and high tolerance to the loss of environmental quality (Vieira \& Shibatta 2007, Araújo et al. 2009, Felipe \& Súarez 2010). The second most representative species in number was Trichomycterus aff. davisi, the only species present in all analyzed segments. This species was collected in fast water microhabitats of the analyzed stretches, being the only species collected in first order segments (V-1 and JP-1). Species of the genus Trichomycterus inhabit small streams with rocky bottom and high water flow (Arratia 1983, Casatti 2003, Chará et al. 2006) and two species of the genus were considered constant in headwater regions of the Capivara river, a mountain stream which first, third and fourth orders segments were analyzed by Uieda \& Barreto (1999), located in the Tietê river basin in São Paulo. The genus Trichomycterus was also considered to be a group of species characteristic of headwaters of mountain streams by Buckup (1999).

No temporal influence was observed in the distribution of fish species in the analyzed mountain streams. This seems to be a pattern for all low-order streams of the Neotropical region (e.g., Vilella 2002, Langeani et al. 2005, Valério et al. 2007, Súarez 2008, Súarez \& LimaJúnior 2009) because the temporal variation is mainly associated with the fish migration from the lower portions of the basin (Grossman \& Ratajczak Junior 1998) and, as these streams present a small temporal variation of their hydrological characteristics (Súarez \& Petrere Junior 2005) and also a higher stability than the higher order segments, with an almost constant energy flow throughout the year (Dudgeon 2008), they act as a "filter of species" (Poff 1997), preventing the colonization of migratory species in these environments.

The analysis of similarity showed significant difference among the fish assemblage in the sampled segments, and the cluster and MDS analysis showed that the fish assemblages are similar along these three streams. All headwater and middle segments of the three sampled streams formed the group B in the cluster analysis. According to the order classification of the channel segments, it was expected that the 
Table 2. Number of specimens of the fish species sampled in the Varanal, João Pinheiro and Rio Preto streams.

\begin{tabular}{|c|c|c|c|c|c|c|c|c|c|}
\hline \multirow[t]{2}{*}{ Taxa } & \multicolumn{3}{|c|}{ Varanal } & \multicolumn{3}{|c|}{ João Pinheiro } & \multicolumn{3}{|c|}{ Rio Preto } \\
\hline & $\mathrm{V}-1$ & $\mathrm{~V}-2$ & $\mathrm{~V}-3$ & JP-1 & JP-2 & JP-3 & RP-1 & RP-2 & RP-3 \\
\hline \multicolumn{10}{|l|}{ Order Characiformes } \\
\hline \multicolumn{10}{|l|}{ Family Characidae } \\
\hline Astyanax aff. paranae Eigenmann, 1914 & - & 21 & 39 & - & 7 & 2 & 1 & 26 & 28 \\
\hline Astyanax altiparanae Garutti \& Britski, 2000 & - & - & - & - & 6 & - & - & - & - \\
\hline Oligosarcus paranensis Menezes \& Géry, 1983 & - & - & - & - & - & - & - & - & 3 \\
\hline Bryconamericus aff. iheringii (Boulenger, 1887) & - & - & - & - & - & 10 & - & - & - \\
\hline Bryconamericus stramineus Eigenmann, 1908 & - & - & 5 & - & - & - & - & - & - \\
\hline Hyphessobrycon boulengeri Eigenmann, 1907 & - & - & 1 & - & - & - & - & - & - \\
\hline Piabina argentea Reinhardt, 1867 & - & - & 87 & - & 1 & - & - & - & - \\
\hline \multicolumn{10}{|l|}{ Family Erythrinidae } \\
\hline Hoplias malabaricus (Bloch, 1794) & - & - & - & - & - & 5 & - & - & 2 \\
\hline \multicolumn{10}{|l|}{ Family Parodontidae } \\
\hline Apareiodon ibitiensis Amaral Campos, 1944 & - & - & 2 & - & - & - & - & - & 1 \\
\hline Apareiodon piracicabae Eigenmann, 1907 & - & - & 1 & - & - & - & - & - & - \\
\hline \multicolumn{10}{|l|}{ Family Poeciliidae } \\
\hline Phalloceros harpagos Lucinda, 2008 & - & - & 4 & - & 108 & 2 & 89 & 225 & 5 \\
\hline \multicolumn{10}{|l|}{ Order Gymnotiformes } \\
\hline \multicolumn{10}{|l|}{ Family Gymnotidae } \\
\hline Gymnotus sylvius Albert \& Fernandes-Matioli, 1999 & - & - & - & - & - & 1 & - & - & - \\
\hline \multicolumn{10}{|l|}{ Order Perciformes } \\
\hline \multicolumn{10}{|l|}{ Family Cichlidae } \\
\hline Geophagus brasiliensis (Quoy \& Gaimard, 1824) & - & - & 1 & - & - & 17 & - & - & - \\
\hline \multicolumn{10}{|l|}{ Order Siluriformes } \\
\hline \multicolumn{10}{|l|}{ Family Callichthyidae } \\
\hline Corydoras ehrhardti Steindachner, 1910 & - & - & - & - & 8 & 104 & - & - & - \\
\hline Corydoras paleatus (Jenyns, 1842) & - & - & 1 & - & - & - & - & - & - \\
\hline \multicolumn{10}{|l|}{ Family Heptapteridae } \\
\hline Rhamdia quelen (Quoy \& Gaimard, 1824) & - & - & 1 & - & - & - & - & - & 10 \\
\hline \multicolumn{10}{|l|}{ Family Loricariidae } \\
\hline Hypostomus ancistroides (Ihering, 1911) & - & - & 14 & - & - & - & - & - & 15 \\
\hline $\begin{array}{l}\text { Isbrueckerichthys calvus Jerep, Shibatta, Pereira \& Oyakawa, } \\
2006\end{array}$ & - & - & - & - & - & - & - & - & 1 \\
\hline Hisonotus francirochai (Ihering, 1928) & - & - & - & - & 1 & 1 & - & - & - \\
\hline Otothyropsis sp. & - & - & 1 & - & 2 & 3 & - & - & - \\
\hline \multicolumn{10}{|l|}{ Family Trichomycteridae } \\
\hline \multirow[t]{2}{*}{ Trichomycterus aff. davisi (Haseman, 1911) } & 24 & 79 & 39 & 17 & 17 & 13 & 25 & 25 & 3 \\
\hline & 24 & 100 & 196 & 17 & 150 & 158 & 115 & 276 & 68 \\
\hline
\end{tabular}

Table 3. Results of the canonical correspondence analysis (CCA, canonical coefficients [CCA1 and CCA2] and coefficient of determination [ $\left.\mathrm{r}^{2}\right]$ ), of the environmental variables in Varanal, João Pinheiro and Rio Preto streams. $*=$ significant at $\alpha \leq 0.05 ; * *=$ significant at $\alpha \leq 0.01 ; * * *=$ significant at $\alpha \leq 0.001$.

\begin{tabular}{lcrc}
\hline & CCA1 & CCA2 & $\mathbf{r}^{2}$ \\
\hline Altitude & 0.3150 & -0.8143 & 0.0440 \\
Width & 0.4798 & -0.5515 & $0.3152 * * *$ \\
Depth & 0.2560 & -0.4220 & $0.2626 *$ \\
Water speed & 0.3747 & 0.0808 & $0.5291 * * *$ \\
Flow rate & 0.4403 & -0.4193 & $0.3036 *$ \\
pH & 0.8826 & 0.0554 & $0.3417 * * *$ \\
Dissolved oxygen & -0.3493 & -0.2283 & 0.1349 \\
Conductivity & -0.5766 & -0.4540 & $0.2349 * *$ \\
Temperature & -0.3499 & -0.1564 & 0.0292 \\
\hline
\end{tabular}

middle segment of the Rio Preto (RP-2), of third order, was to be grouped with the mouth segments, and not with the first and second order segments. The presence of this stretch in the cluster B can be explained by its historical use, where stones were removed from its bottom. The modification of the substrate of a river influences the physical attributes of the habitat (Karr 1981, Melo et al. 2003, Dias \& Tejerina-Garro 2010), leading to the loss of microhabitats and modification of the structure and composition of the fish assemblage via local extinction of species (Gorman \& Karr 1978, Araújo \& Tejerina-Garro 2009).

The mouth of the Varanal (V-3), of second order, and the mouth of the Rio Preto (RP-3), of third order, formed the group A in the cluster analysis. The segments more distant from the headwaters have a more complex habitat, supporting a higher number of species which variably interact with the environment (Vannote et al. 1980), 


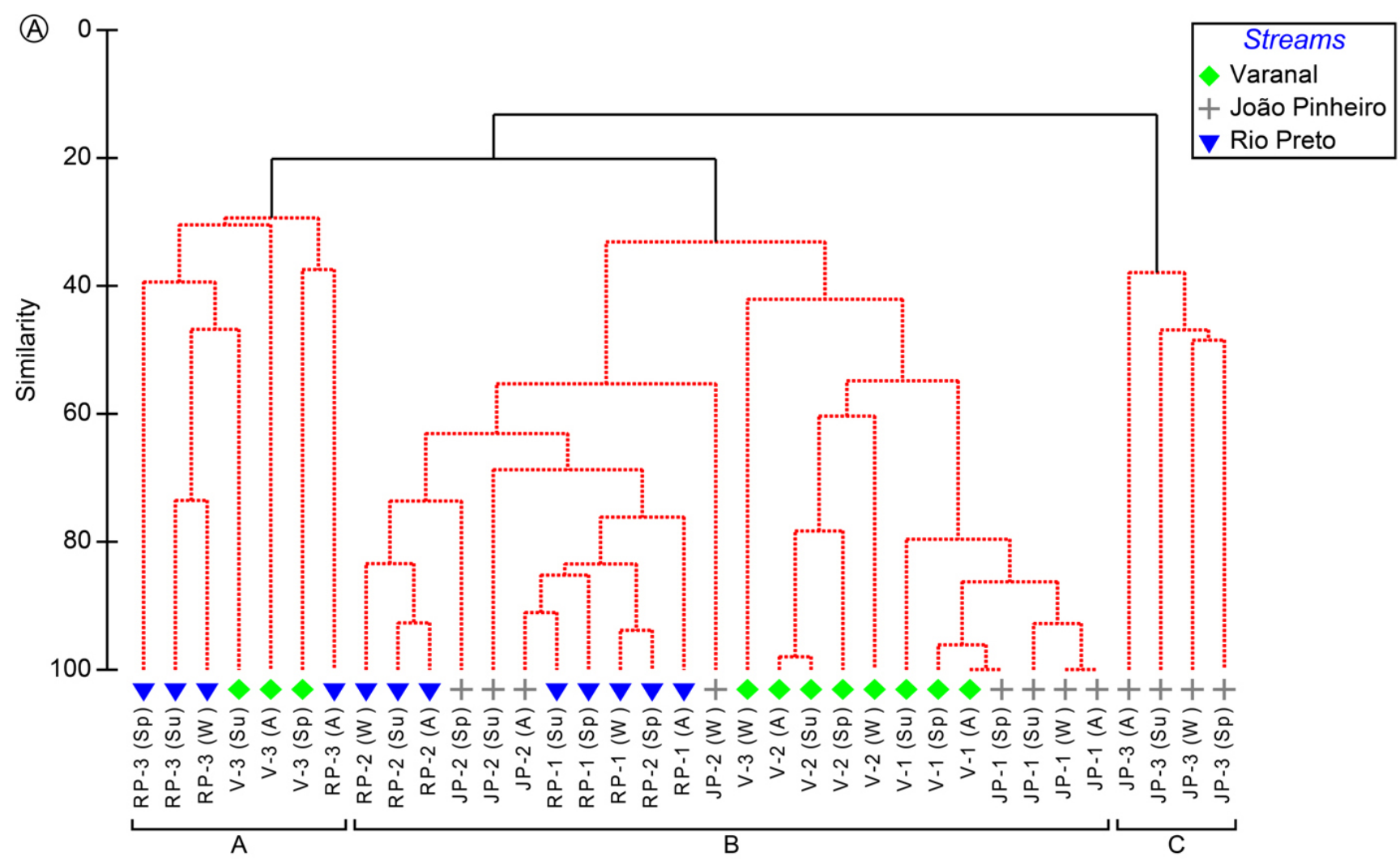

(B)

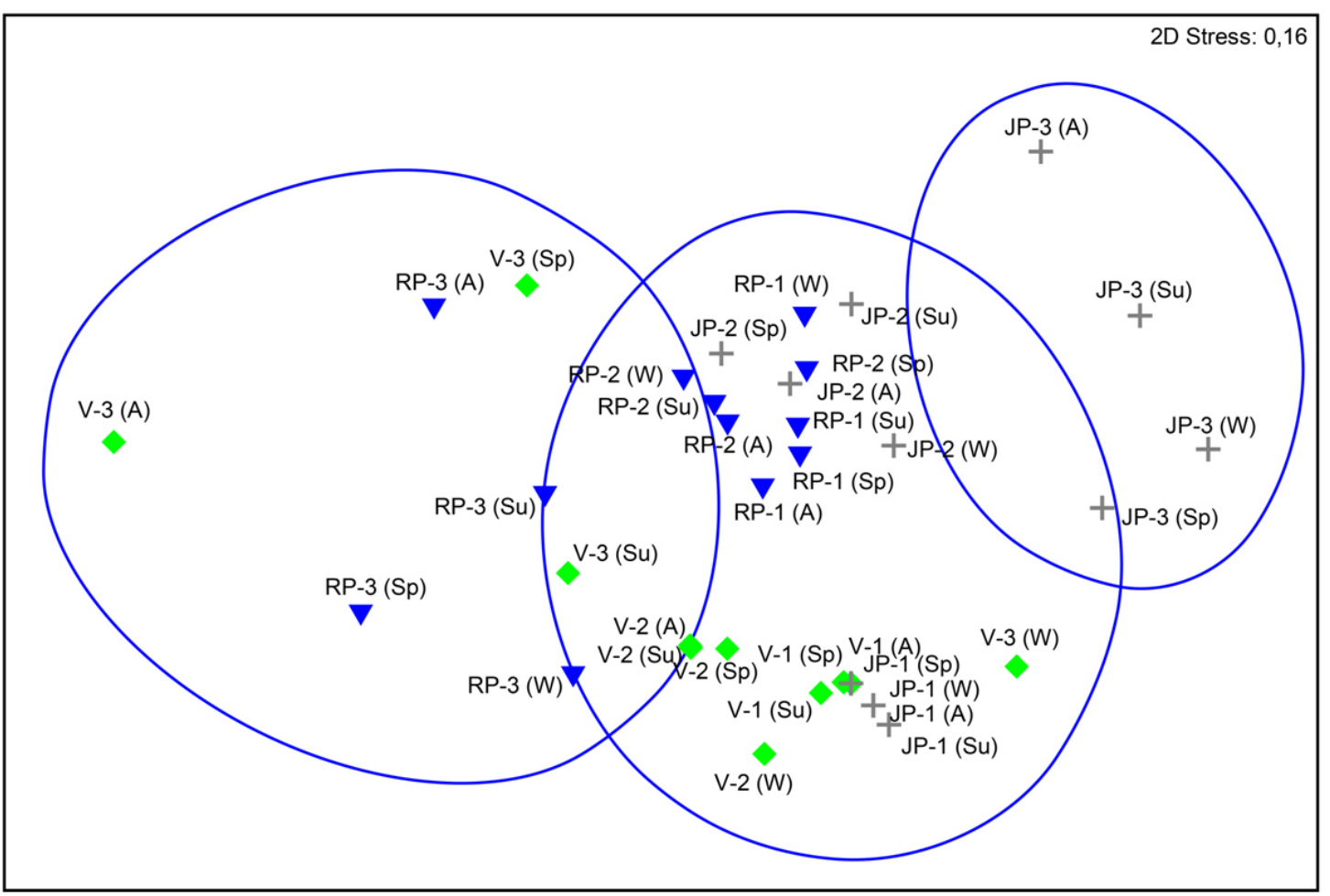

Figure 4. (a) Similarity dendrogram (Bray-Curtis similarity) for sampled segments in the Varanal, João Pinheiro and Rio Preto streams. Solid black lines indicate significant group structure at the $5 \%$ level. (b) Nonmetric multidimensional scaling plot (2-D stress: 0.16 ; 3-D stress: 0.09 ) with superimposed significant clusters at similarity levels of $25 \%$ (Su: summer; A: autumn; W: winter; Sp: spring). 


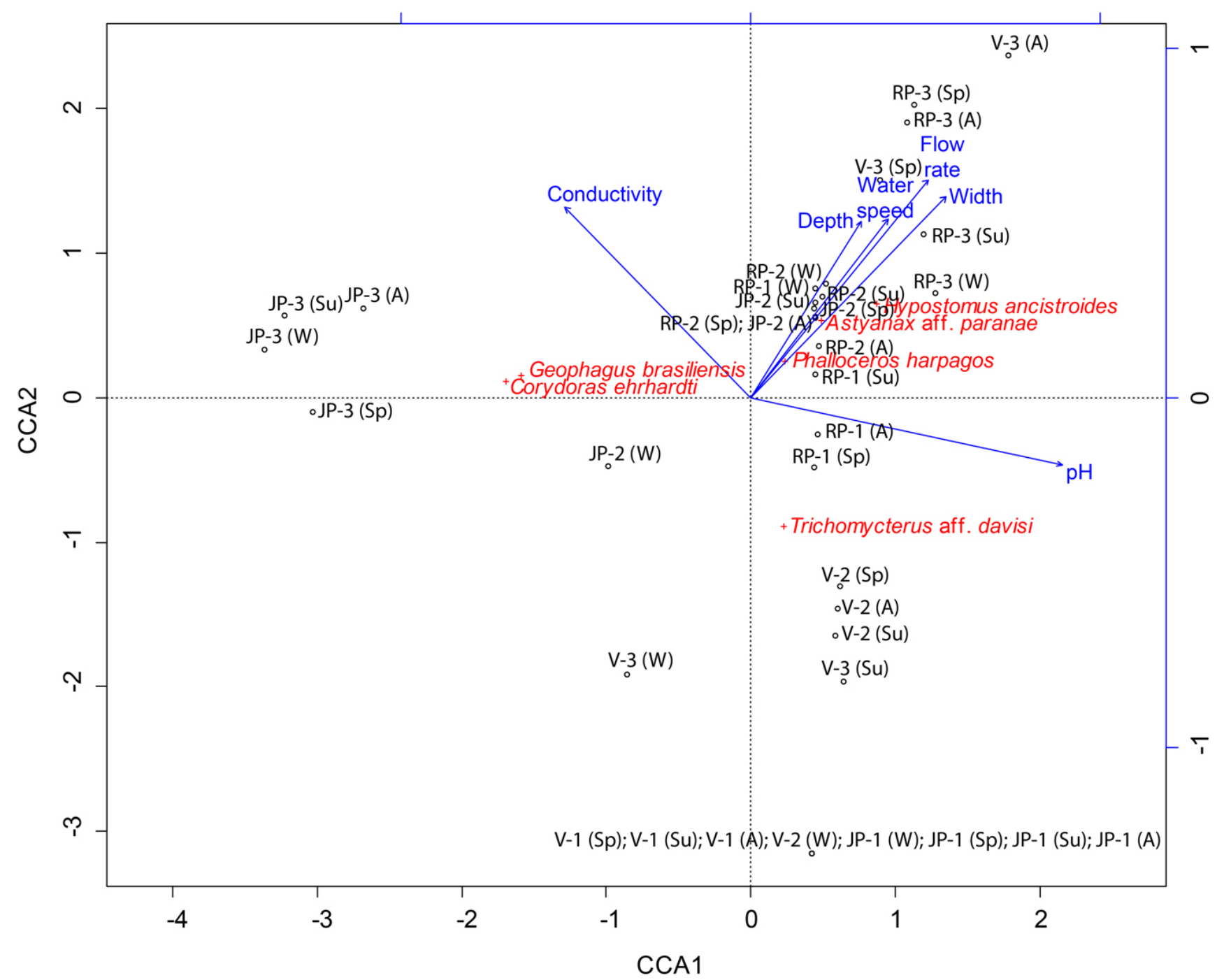

Figure 5. Scatterplot of the two first axis resulted from canonical correspondence analysis (CCA) for the fish assemblages in the Varanal, João Pinheiro and Rio Preto streams (Su: summer; A: autumn; W: winter; Sp: spring).

as observed on the species that characterize this group. Astyanax aff. paranae is a species that inhabits the water column (Shibatta et al. 2002), while Hypostomus ancistroides inhabits the bottom of streams, scraping algae on the substrate (Casatti et al. 2001). The canonical correspondence analysis supports this assumption, as it demonstrates that environmental variables that most influenced the distributional patterns of these species were the stream width, depth, water speed, flow rate, conductivity and $\mathrm{pH}$.

The cluster C, consisting of the lower segment of the João Pinheiro (JP-3), differs from the others by the presence of structural alterations, which eliminated the mountain stream characteristics. This situation is evidenced by the species that define this group, Geophagus brasiliensis and Corydoras ehrhardti. Species of the genera Corydoras prefers sand deposition areas and G. brasiliensis is a species with opportunistic behavior, found in pools (Casatti et al. 2001, Shibatta et al. 2008). The canonical correspondence analysis also showed that $C$. ehrhardti and G. brasiliensis are related to narrower and shallower waters, with low $\mathrm{pH}$ and high conductivity.

It was observed that the mountain streams herein analyzed present some patterns in the structure of the ichthyofauna. The streams presented a similar ichthyofauna and no temporal variation was found in the species composition. The low order segments closer to the headwaters were similar, mainly due to the occurrence of $T$. aff. davisi found in the three streams, and as the volume of water increases, the assembly becomes characterized by the presence of other species which exploit the environment in variable ways. It was also observed that the relative position of each stretch in the basin were more important than their order to define the similarity between them. However these patterns still need to be better assessed by a comparison with other mountain streams from the Atlantic Forest and also with other stream categories to determine how they differ. It is also evident that there is still much basic information to be known about dynamics of mountain streams of the Atlantic Rain Forest, such as taxonomic inventories and studies of species biology, an important data for the understanding, management and conservation of the Atlantic Rain Forest biome.

\section{Acknowledgments}

We are grateful to Alexander Claro García, Mario Roberto Castro Meira Filho, Matheus Zaqueu de Lima, Alessandro Borini Lone and Edison Santana da Silva for the assistance on field work. To Oscar Akio Shibatta (Museu de Zoologia da Universidade Estadual de Londrina) for the species identification and the help with data 
Silva, J.F.M. et al.

analysis. To CAPES for the financial support and to Elaine Antoniassi Luiz Kashiwaqui and referees for the valuable contributions which improved the manuscript.

\section{References}

ABILHOA, V., BRAGA, R.R., BORNATOWSKI, H. \& VITULE, J.R.S. 2011. Fishes of the Atlantic Rain Forest streams: Ecological Patterns and Conservation. In Changing diversity in changing environment (O. Grillo, ed.). InTech, Croatia, p.259-282. http://dx.doi.org/10.5772/24540

ARAÚJO, F.G., PEIXOTO, M.G., PINTO, B.C.T. \& TEIXEIRA, T.P. 2009. Distribution of guppies Poecilia reticulata (Peters, 1860) and Phalloceros caudimaculatus (Hensel, 1868) along a polluted stretch of the Paraíba do Sul River, Brazil. Braz. J. Biol. 69(1):41-48. PMid:19347144. http:// dx.doi.org/10.1590/S1519-69842009000100005

ARAÚJO, N.B. \& TEJERINA-GARRO, F.L. 2009. Influence of environmental variables and anthropogenic perturbations on stream fish assemblages, Upper Paraná River, Central Brazil. Neotrop. Ichthyol. 7(1):31-38. http:// dx.doi.org/10.1590/S1679-62252009000100005

ARRATIA, G. 1983. Preferencias de habitat de peces siluriformes de aguas continentales de Chile (Fam. Diplomystidae y Trichomycteridae). Stud. Neotrop. Fauna E. 18(4):217-237. http://dx.doi. org/10.1080/01650528309360637

AZEVEDO, T.I.N., SEKIAMA, M.L., VIEIRA, A.O.S. \& BENNEMANN, S.T. 2008. Descrição física da micro bacia do Ribeirão Varanal e caracterização dos trechos. In A flora e a fauna do Ribeirão Varanal: um estudo da biodiversidade no Paraná (S.T. Bennemann, O.A. Shibatta \& A.O.S. Vieira, orgs). EdUEL, Londrina, p.5-14. PMid:20059806.

BARRELLA, W., PETRERE Jr., M., SMITH, W.S. \& MONTAG, L.F.A. 2000. As relações entre matas ciliares, os rios e os peixes. In Matas Ciliares: conservação e recuperação (R.R. Rodrigues \& H.F. Leitão Filho, eds). EdUSP, São Paulo, p.187-207.

BENNEMANN, S.T., SILVA-SOUZA, Â.T. \& ROCHA, G.R.A. 1995. Composicion ictiofaunistica em cinco localidades de la cuenca del rio Tibagi, PR - Brasil. Interciencia. 20(1):7-13.

BENNEMANN, S.T. \& GALVES, W. 2008. Metodologia de amostragem da fauna aquática. In A flora e a fauna do Ribeirão Varanal: um estudo da biodiversidade no Paraná (S.T. Bennemann, O.A. Shibatta \& A.O.S. Vieira, orgs). EdUEL, Londrina, p.69-76.

BENNEMANN, S.T., SHIBATTA, O.A. \& VIEIRA, A.O.S. 2008. Síntese e medidas de conservação. In A flora e a fauna do Ribeirão Varanal: um estudo da biodiversidade no Paraná (S.T. Bennemann, O.A. Shibatta \& A.O.S. Vieira, orgs). EdUEL, Londrina, p.69-76.

BRASIL. Ministério do Meio Ambiente - MMA. 2002. Biodiversidade Brasileira: avaliação e identificação de áreas e ações prioritárias para conservação, utilização sustentável e repartição de benefícios da biodiversidade brasileira. MMA, Brasília, 404p.

BUCKUP, P.A. 1999. Sistemática e biogeografia de peixes de riachos. In Ecologia de peixes de riachos: Estado Atual e Perspectivas (E.P. Caramaschi, R. Mazzoni, C.R.S.F. Bizerril \& P.R. Peres-Neto, eds). Oecol. Bras. 6:91-138.

CASATTI, L., LANGEANI, F. \& CASTRO, R.M.C. 2001. Peixes de riacho do Parque Estadual Morro do Diabo, bacia do Alto Paraná, SP. Biota Neotrop. 1(12): http://www.biotaneotropica.org.br/v1n12/pt/abstract?i nventory+BN00201122001

CASATTI, L. 2003. Biology of a Catfish, Trichomycterus sp. (Pisces, Siluriformes), in a Pristine Stream in the Morro do Diabo State Park, Southeastern Brazil. Stud. Neotrop. Fauna E. 38(2):105-110. http://dx.doi. org/10.1076/snfe.38.2.105.15928

CASTRO, R.M.C. 1999. Evolução da ictiofauna de riachos sul-americanos: padrões gerais e possíveis processos causais. In Ecologia de Peixes de Riachos: Estado Atual e Perspectivas (E.P. Caramaschi, R. Mazzoni, C.R.S.F. Bizerril, P.R. Peres-Neto, eds.). Oecol. Bras. 6:139-155.
CHARÁ, J.D., BAIRD, D.J., TELFER, T.C. \& RUBIO, E.A. 2006. Feeding ecology and habitat preferences of the catfish genus Trichomycterus in low-order streams of the Colombian Andes. J. Fish Biol. 68(4):1026-1040. http://dx.doi.org/10.1111/j.0022-1112.2006.00984.x

CLARKE, K.R. 1993. Non-parametric multivariate analyses of changes in community structure. Aust. J. Ecol. 18(1):117-143. http://dx.doi. org/10.1111/j.1442-9993.1993.tb00438.x

CLARKE, K.R. \& GORLEY, R.N. 2006. PRIMER v6: User Manual/Tutorial. PRIMER-E, Plymouth.

COUTO, T.B.A. \& AQUINO, P.D.P.U. 2011. Structure and integrity of fish assemblages in streams associated to conservation units in Central Brazil. Neotrop. Ichthyol. 9(2):445-454. http://dx.doi.org/10.1590/S167962252011000200023

DIAS, A.M. \& TEJERINA-GARRO, F.L. 2010. Changes in the structure of fish assemblages in streams along an undisturbed-impacted gradient, upper Paraná River basin, Central Brazil. Neotrop. Ichthyol. 8(3):587-598. http://dx.doi.org/10.1590/S1679-62252010000300003

DUDGEON, D. 2008. Tropical Stream Ecology. Academic Press, London.

FELIPE, T.R.A. \& SÚAREZ, Y.R. 2010. Characterization and influence of environmental factors on stream fish assemblages in two small urban sub-basins, Upper Paraná River. Biota Neotrop. 10(2): http://www. biotaneotropica.org.br/v10n2/en/abstract?article+bn03810022010

FUNDAÇÃO SOS MATA ATLÂNTICA \& INSTITUTO NACIONAL DE PESQUISAS ESPACIAIS - INPE. 2011. Atlas dos remanescentes florestais da Mata Atlântica período 2008-2010. São Paulo.

GORMAN, O.T. \& KARR, J.R. 1978. Habitat structure and stream fish community. Ecology. 59(3):507-516. http://dx.doi.org/10.2307/1936581

GROSSMAN, G.D. \& RATAJCZAK JUNIOR, R.E.1998. Long-term patterns of microhabitat use by fish in a southern Appalachian stream from 1983 to 1992: effects of hydrologic period, season and fish length. Ecol. Freshw. Fish 7:108-131. http://dx.doi.org/10.1111/j.1600-0633.1998.tb00178.x

INSTITUTO DE TERRAS, CARTOGRAFIA E GEOCIÊNCIAS - ITCG. 2011. Arquivo Vetorial - Formato Shapefile - da hidrografia do Estado do Paraná. http://www.itcg.pr.gov.br/ (último acesso em 26/04/2012)

KARR, J.R. 1981. Assessment of biotic integrity using fish communities. Fisheries 6(1):21-27. http://dx.doi.org/10.1577/15488446(1981)006<0021:AOBIUF $>2.0 . \mathrm{CO} ; 2$

LANGEANI, F., CASATTI, L., GAMEIRO, H.S., CARMO, A.B. \& ROSSAFERES, D.C. 2005. Riffle and pool fish communities in a large stream of southeastern Brazil. Neotrop. Ichthyol. 3(2):305-311. http://dx.doi. org/10.1590/S1679-62252005000200009

LANGEANI, F., CASTRO, R.M.C., OYAKAWA, O.T., SHIBATTA, O.A., PAVANELLI, C.S. \& CASATTI, L. 2007, Biota Neotrop. 7(3): http:// dx.doi.org/10.1590/S1676-06032007000300020

LOWE-McCONNELL, R.H. 1999. Estudos eológico de comunidades de peixes tropicai. EdUSP, São Paulo.

MEDRI, M.E., BIANCHINI, E., SHIBATTA, O.A. \& PIMENTA, J.A. 2002. A Bacia do rio Tibagi. EDUEL, Londrina.

MELO, C.E., MACHADO, F.A. \& PINTO-SILVA, V. 2003. Diversidade de peixes em um córrego de Cerrado no Brasil central. Braz. J. Ecol. 1(2):17-23.

OKSANEN, J. 2011. Multivariate analysis of ecological communities in R: vegan tutorial. http://cc.oulu.fi/ jarioksa/softhelp/vegan.html (último acesso em 20/06/2012).

POFF, N.L. 1997. Landscape filters and species traits: towards mechanistic understanding and prediction in stream ecology. J. N. Am. Benthol. Soc. 16:391-409. http://dx.doi.org/10.2307/1468026

R DEVELOPMENT CORE TEAM. 2012. R: A language and environment for statistical computing. R Foundation for Statistical Computing, Vienna.

SANTOS, G.M. \& FERREIRA, E.J.G. 1999. Peixes da bacia Amazônica. In Estudos ecológicos de comunidades de peixes tropicais (R.H. LoweMcConnell). EdUSP, São Paulo, p.345-373. 
SHIBATTA, O.A., ORSI, M.L., BENNEMANN S.T. \& SILVA-SOUZA Â.T. 2002. Diversidade e distribuição de Peixes na bacia do rio Tibagi. In A Bacia do rio Tibagi. (M.E. Medri, E. Bianchini, O.A. Shibatta \& J.A. Pimenta, eds). EdUEL, Londrina, p.403-424

SHIBATTA, O.A. \& CHEIDA, C. 2003. Composição em tamanho dos peixes (Actinopterygii, Teleostei) de ribeirões da bacia do rio Tibagi, Paraná, Brasil. Rev. Bras. Zool. 20(3):469-473. http://dx.doi.org/10.1590/S010181752003000300016

SHIBATTA, O.A., GEALH, A.M. \& BENNEMANN, S.T. 2007. Ictiofauna dos trechos alto e médio da bacia do rio Tibagi, Paraná, Brasil. Biota Neotrop. 7(2): http://www.biotaneotropica.org.br/v7n2/pt/ abstract?article+bn02107022007

SHIBATTA, O.A., BENNEMANN, S.T., MORI, H. \& SILVA, D.F. 2008. Riqueza biológica e ecológica dos peixes do Ribeirão Varanal. In A flora e a fauna do Ribeirão Varanal: um estudo da biodiversidade no Paraná (S.T. Bennemann, O.A. Shibatta \& A.O.S. Vieira, orgs.). EdUEL, Londrina, p.77-98.

STRAHLER, A.N. 1957. Quantitative analysis of watershed geomorphology. Eos. T. Am. Geophys. Un. 8(6):913-920. http://dx.doi.org/10.1029/ TR038i006p00913

SÚAREZ, Y.R. \& PETRERE JUNIOR, M. 2005. Organização das assembleias de peixes em riachos da bacia do rio Iguatemi, Mato Grosso do Sul. Acta Sci. Biol. Sci. 22(2):161-167.

SÚAREZ, Y.R. 2008. Variação especial e temporal na diversidade e composição de espécies de peixes em riachos da bacia do Rio Ivinhema, Alto Rio Paraná. Biota Neotrop. 8(3): http://www.biotaneotropica.org. br/v8n3/en/abstract?article+bn02308032008
SÚAREZ, Y.R. \& LIMA-JÚNIOR, S.E. 2009. Variação espacial e temporal nas assembleias de peixes de riachos na bacia do rio Guiraí, Alto Rio Paraná. Biota Neotrop. 9(1): http://www.biotaneotropica.org.br/v9n1/en/ abstract?article+bn01709012009

TER BRAAK, C.J.F. 1986. Canonical correspondence analysis: a new eigenvector technique for multivariate direct analysis. Ecol. 67(5):11671179. http://dx.doi.org/10.2307/1938672

UIEDA, V.S. \& BARRETO, M.G. 1999. Composição da ictiofauna de quatro trechos de diferentes ordens do rio Capivara, bacia do Tietê, Botucatu, São Paulo. Rev. Bras. Zoocien. 1(1):55-67.

VALÉRIO, S.B., SÚAREZ, Y.R., FELIPE, T.R.A., TONDATO, K.K. \& XIMENES, L.Q.L. 2007. Organization patterns of headwater-stream fish communities in the Upper Paraguay-Paraná basins. Hydrobiologia. 583(1):241-250. http://dx.doi.org/10.1007/s10750-006-0533-1

VANNOTE, R.L., MINSHALL, G.W., CUMMINS, K.W., SEDELL, J.R. \& CUSHING, C.E. 1980. The river continuum concept. Can. J. Fish. Aquat. Sci. 37:130-137. http://dx.doi.org/10.1139/f80-017

VIEIRA, D.B. \& SHIBATTA, O.A. 2007. Peixes como indicadores da qualidade ambiental do ribeirão Esperança, Município de Londrina, Paraná, Brasil. Biota Neotrop. 7(1): http://www.biotaneotropica.org.br/ v7n1/pt/abstract?article+bn01407012007

VILELLA, F.S. 2002. Ecologia da comunidade aquática de um riacho de $1^{\text {a }}$ ordem da Mata Atlântica: Relações entre variáveis estruturais e bióticas em uma Reserva de Biosfera Tropical. Dissertação de Mestrado, Universidade Federal de São Carlos, São Carlos. 